\title{
Effect of Non-Thermal Plasma Modified NiAl Layered Double Hydroxides on the Removal of Fluoride from Aqueous Solution
}

\author{
Hongxiao Lu, Qiurong Li*, Haiyan Xiao, Ranran Wang, Danyang Xie \\ Hebei Key Laboratory of Applied Chemistry, School of Environmental and Chemical Engineering, Yanshan \\ University, Qinhuangdao, China \\ Email: liqiurong63@aliyun.com
}

Received 15 April 2014; revised 29 May 2014; accepted 13 June 2014

Copyright $@ 2014$ by authors and Scientific Research Publishing Inc.

This work is licensed under the Creative Commons Attribution International License (CC BY).

http://creativecommons.org/licenses/by/4.0/

(c) (i) Open Access

\begin{abstract}
In this paper, NiAl layered double hydroxides (NiAl-LDHs) has been modified by non-thermal plasma (NTP) to enhance the fluoride removal capacity of materials. The samples were characterized by X-ray diffraction, Fourier transform infrared spectrometer (FTIR), Thermogravimetric differential thermal analyzer (TG-DTA) and $\mathrm{N}_{2}$ adsorption-desorption. Effects of $\mathbf{p H}$, co-existing anions, temperature and kinetics on $\mathrm{F}^{-}$adsorption were investigated. The results showed that $\mathrm{pH}$ affects the adsorbent surface charge. The effective $\mathrm{pH}$ range for $\mathrm{F}^{-}$removal was between 4.5 and 10. Lower pH potentially causes dissolution of NiAl-LDHs. The negligible interference of coexisting ions such as $\mathrm{NO}_{2}^{-}, \mathrm{MnO}_{4}^{-}, \mathrm{C}_{2} \mathrm{O}_{4}^{2-}$ makes the $\mathrm{NiAl}-\mathrm{LDHs}$ a promising sorbent for fluoride polluted water treatment.
\end{abstract}

Keywords

Adsorption, NiAl Layered Double Hydroxides, Non-Thermal Plasma, Fluoride

\section{Introduction}

Increasing worldwide pollutants of freshwater systems have become one of the key environmental problems facing humanity. Among all water contaminations, fluoride is the most abundant anions present in groundwater worldwide and creates a major problem in safe drinking water supply. Excess fluoride ingestion for a long time would lead to dental and skeletal fluorosis, bone disease, and nonskeletal fluorosis [1]. According to the World Health Organization, the maximum acceptable concentration of fluoride in drinking water is $1.5 \mathrm{mg} / \mathrm{L}$ [2]. Thus,

*Corresponding author.

How to cite this paper: Lu, H.X., Li, Q.R., Xiao, H.Y., Wang, R.R. and Xie, D.Y. (2014) Effect of Non-Thermal Plasma Modified NiAl Layered Double Hydroxides on the Removal of Fluoride from Aqueous Solution. American Journal of Analytical Chemistry, 5, 547-558. http://dx.doi.org/10.4236/ajac.2014.59062 
the removal of fluoride ions from nature water is becoming a crucial issue. Various techniques have been applied to removal of fluoride ion from water. Compared to other techniques such as electrocoagulation [3] [4], reverse osmosis [5], ion exchange [6], membrane techniques [7], and biological treatment [8], adsorption is considered as one of the most promising technologies [9] owing to its cost-effective, versatile, and operational simplicity for the removing trace levers of fluoride anions. To meet the fast-developing water treatment requirements, there is a great need to devise new and innovative technologies and materials for efficient removal of fluoride from aqueous solutions.

Recently, layered double hydroxides (LDHs) have attracted considerable attention owing to their large surface area, high anion exchange capacity and thermal stability [10]. LDHs are one of the most useful classes of inorganic layered materials with the general formula of $\left[\mathrm{M}_{1-\mathrm{x}}^{2+} \mathrm{M}_{\mathrm{x}}^{3+}\left(\mathrm{OH}_{2}\right)\right] \mathrm{A}_{\mathrm{x} / \mathrm{n}}^{\mathrm{n}-} \cdot \mathrm{mH}_{2} \mathrm{O}$, where $\mathrm{M}^{2+}$ and $\mathrm{M}^{3+}$ are respectively divalent and trivalent cations, the value of the coefficient $\mathrm{x}$ is equal to the molar ratio $\mathrm{M}^{3+} /\left(\mathrm{M}^{2+}+\mathrm{M}^{3+}\right)$, ( $\mathrm{x}$ is usually $0.20-0.33$ ) and $\mathrm{A}^{\mathrm{n}-}$ is an anion with charge $\mathrm{n}$ [11]. Replacement of some fraction of the divalent ions by a trivalent ion of comparable size leads to a net positive charge on the layers. The positive charge is balanced by anions in the interlayer [12]. The exchangeable interlayer anions of LDHs, incorporating a variety of anions, make them excellent adsorbents in water cleanup. Yunmin et al. [13] synthesized a hierarchical nano/micro-structured Zn-Mg-Al LDHs by the urea method and used to absorbed of methyl orange. Ling et al. [14] successfully synthesized $\mathrm{NiAl}$ mixed oxides by urea hydrolysis approach, and employed for $\mathrm{SO}_{2}$ removal. Jinbo et al. [15] synthesis of self-assembled layered double hydroxides/carbon composites by in situ solvothermal method. In addition, reduction-oxidation [16] and microwave-assisted methods [17] have also been widely used. Zheng et al. [13] reported that hierarchical nano/micro-structured Zn-Mg-Al layered double hydroxides show high adsorption property for removing organic pollutants. Garcia-Gallastegui and Iruretagoyena [18] fabricated graphene oxide/LDHs for enhancing the $\mathrm{CO}_{2}$ adsorption capacity. Zhou et al. [19] synthesized hollow microspheres of Zn-Al LDHs showing high binding capacity for phosphate, resulting the maximum adsorption capacity of $232 \mathrm{mg} / \mathrm{g}$. The removal of fluoride from aqueous solution using the original and non-thermal plasma (NTP) modified $\mathrm{CeO}_{2} / \mathrm{Al}_{2} \mathrm{O}_{3}$ composites have been studied systematically [20].

NTP is a high energetic state of matter that is characterized by high degree of ionization [21] [22]. In the plasma, high-energy electrons dissociate the feed gas into atoms, enabling high reactivity. In addition, plasma treatment process does not pollute the environment. In recent years, with the development of plasma technology, using of plasma to modify the surface of materials has become interesting in some researches [23]. After modified by NTP the surface of materials became rough, new chemical species were introduced and the contaminants were removed. These advantages can be very important for adsorption process, because almost all adsorption processes are surface phenomena and the active species such as high-energy electrons and reactive radicals generated by plasma can activate the upper molecular layers of the interface.

In this study, NTP was used to modify the surface state of NiAl-LDHs materials. NTP treatment can change the surface properties of adsorbents and improved adsorption capacity for fluoride ion. The main objectives of this paper were 1) to investigate the structure of NiAl-LDHs treated by NTP via XRD, FTIR, and $\mathrm{N}_{2}$ adsorption/desorption, 2) to evaluate the effect of initial $\mathrm{pH}$, contact time and interfering ions on fluoride removal by batch experiments, and 3) to investigate the kinetics of fluoride adsorption by kinetic models.

\section{Experimental Section}

\subsection{Synthesis of NiAl-LDHs}

Analytical-grade chemicals $\left[\mathrm{Ni}\left(\mathrm{NO}_{3}\right)_{2} \cdot 6 \mathrm{H}_{2} \mathrm{O}, \mathrm{Al}\left(\mathrm{NO}_{3}\right)_{3} \cdot 9 \mathrm{H}_{2} \mathrm{O}, \mathrm{NaF}, \mathrm{NH}_{3} \cdot \mathrm{H}_{2} \mathrm{O}, \mathrm{C}_{6} \mathrm{H}_{5} \mathrm{Na}_{3} \mathrm{O}_{7} \cdot 2 \mathrm{H}_{2} \mathrm{O}, \mathrm{NaNO}_{3}\right]$ were used for NiAl-LDHs preparation. Total ionic strength adjustment buffer solution (TISAB) were prepared by $\mathrm{NaNO}_{3}$ and $\mathrm{C}_{6} \mathrm{H}_{5} \mathrm{Na}_{3} \mathrm{O}_{7} \cdot 2 \mathrm{H}_{2} \mathrm{O}$ at $\mathrm{pH}$ ranging from 5 to 6 . Deionized water was used to prepare all solutions in this study.

$\mathrm{NiAl}-\mathrm{LDHs}$ were prepared by the co-precipitation method. In a typical procedure, A total of $0.05 \mathrm{~mol} \mathrm{Ni}$ $\left(\mathrm{NO}_{3}\right)_{2} \cdot 6 \mathrm{H}_{2} \mathrm{O}$ and $0.025 \mathrm{~mol} \mathrm{Al}\left(\mathrm{NO}_{3}\right)_{3} \cdot 9 \mathrm{H}_{2} \mathrm{O}$ were dissolved in $200 \mathrm{~mL}$ deionized water. The solution was magnetically stirred for $10 \mathrm{~min}$ in air at room temperature. Subsequently, the solution was titrated with an alkali solution of $\mathrm{NH}_{3} \cdot \mathrm{H}_{2} \mathrm{O}(10 \%)$ under vigorous stirring at $80^{\circ} \mathrm{C}$ at such a rate that the $\mathrm{pH}$ of the reaction mixture was maintained at $10.0( \pm 0.5)$. The resulting suspension was further stirring for $1 \mathrm{~h}$, and then transferred to a water bath aged at $90^{\circ} \mathrm{C}$ for $24 \mathrm{~h}$. The solid was then recovered and washed with deionized water and finally dried at $80^{\circ} \mathrm{C}$ for $12 \mathrm{~h}$, the sample was denoted as NiAl-LDHs. 


\subsection{NTP Modified NiAl-LDHs}

The NiAl-LDHs were treated by NTP (CTP-2000K plasma generator, Nanjing Suman electronic co., LTD, China) before calcinations. The power of NTP treatment was $60 \mathrm{~W}$, and the duration time was 10 min, then the modified material was obtained, the sample was denoted as NiAl-LDHs (P).

\subsection{Structural Characterizations}

X-ray diffraction (XRD) patterns were collected using a D/MAX-2500/PC diffractometer with CuK $\alpha$ radiation $(\lambda=1.54056 \AA)$ from $5^{\circ}$ to $80^{\circ}(2 \theta)$ at a scanning rate of $5^{\circ} / \mathrm{min}$. For the determination of the average crystallites size the Scherrer formula [24] has been used (Equation (1)):

$$
\mathrm{D}_{\mathrm{v}}=\frac{0.89 \lambda}{\beta \cos \theta}
$$

where $\mathrm{D}_{\mathrm{v}}$ is the volume weighted crystallite size, $\lambda$ the wavelength $(\mathrm{CuK} \alpha), \beta$ is the full-width at the half-maximum intensity, $\theta$ the diffraction angle corresponding to the $(00 l)$ diffraction line. FTIR were recorded on a Nicolet is 10 spectrometer over a range from 500 to $4000 \mathrm{~cm}^{-1}$. The thermal behavior of the samples was determined by thermogravimetric analysis (TGA) using a DTG 60 instrument in the temperature $30^{\circ} \mathrm{C}-800^{\circ} \mathrm{C}$ with a heating rate of $10^{\circ} \mathrm{C} \cdot \mathrm{min}^{-1} \cdot \mathrm{N}_{2}$ adsorption-desorption was performed with a NOVA-4000e system utilizing Brunauer-Emmett-Teller (BET) for surface area calculation [25]. The pore size distribution and pore volume were obtained using the Barrett-Joyner-Halenda (BJH) method from the adsorption and desorption isotherms, respectively. Before analysis, the samples were pretreated at $80^{\circ} \mathrm{C}$ for $12 \mathrm{~h}$.

\subsection{Adsorption Experiments}

The fluoride adsorption experiments were carried out by batch experiments. All adsorption tests were carried out by a Fluoride ion selective electrode (pF-1) and reference electrode (232).

\subsubsection{Effect of Initial Solution $\mathrm{pH}$}

The effect of initial solution $\mathrm{pH}$ on fluoride adsorption was evaluated by making a series of 100 mg/L fluoride solution at an adsorbent dosage $2 \mathrm{~g} / \mathrm{L}$, the starting solution $\mathrm{pH}$ was adjusted using $\mathrm{HCl}$ and $\mathrm{NaOH}$ to the designed value.

\subsubsection{Effect of Coexistent Anions}

To investigate the selectivity of the synthesized NiAl-LDHs for fluoride in the presence of anions most commonly found in water, including $\mathrm{NO}_{2}^{-}, \mathrm{MnO}_{4}^{-}, \mathrm{HPO}_{4}^{2-}, \mathrm{SO}_{4}^{2-}, \mathrm{CO}_{3}^{2-}, \mathrm{C}_{2} \mathrm{O}_{4}^{2-}$ and $\mathrm{PO}_{4}^{3-}$, the amounts of fluoride adsorbed by $0.1 \mathrm{~g}$ of the NiAl-LDHs from $50 \mathrm{~mL}$ of fluoride solutions containing all 6 anions at a concentration of $100 \mathrm{mg} / \mathrm{L}$ of each anion were determined.

\subsection{Adsorption Kinetic}

The adsorption kinetics of fluoride by the NiAl-LDHs was studied at a solid-to solution ratio of $2 \mathrm{~g} / \mathrm{L}$. The amount of fluoride ion adsorbed per unit mass of the adsorbent $\left(q_{e}\right),\left(q_{t}\right)$ and the removal rate $\left(R_{e}\right)$ were evaluated using the following equations [26]:

$$
\begin{aligned}
& q_{e}=\left(C_{o}-C_{e}\right) V / m \\
& q_{t}=\left(C_{o}-C_{t}\right) V / m \\
& R_{e}=\left(C_{o}-C_{e}\right) / C_{o} \times 100 \%
\end{aligned}
$$

where $C_{o}$ is the initial concentration of fluoride ions in solution $(\mathrm{mg} / \mathrm{L}), C_{e}$ is the equilibrium concentration $(\mathrm{mg} / \mathrm{L}), C_{t}$ is the concentration of fluoride ion at time $t$ of adsorption $(\mathrm{mg} / \mathrm{L}), q_{e}$ is the equilibrium adsorption capacity $(\mathrm{mg} / \mathrm{g}), q_{t}$ is the amount adsorbed per gram of adsorbent at time $t(\mathrm{~min}), V$ is the volume of solution (L), and $m$ is the mass of the sorbent $(\mathrm{g})$. 


\section{Results and Discussion}

\subsection{Characterization of NiAl-LDHs}

The XRD patterns of the NiAl-LDHs and NiAl-LDHs(P) are shown in Figure 1, one can see that the NiAl-LDHs(P) shows diffraction peaks at $2 \theta$ of $11.38^{\circ}, 23.16^{\circ}, 34.76^{\circ}, 39.30,46.80,60.88^{\circ}, 62.14^{\circ}$, which are assigned to the (003), (006), (012), (015), (018), (110) and (113) diffraction, respectively. All of the reflections can be directly indexed to a typical rhombohedral phase hydrotalcite (JCPDS No.54-1030), and no diffraction peaks of impurities were discerned, indicating the high purity of the sample. Moreover, the features of the peaks are sharp, narrow and symmetrical with stable baseline, suggesting that the as-prepared NiAl-LDHs were highly crystallized. NiAl-LDHs (P) has higher intensity and sharper peaks which compare with the NiAl-LDHs samples, indicating that the application of NTP process promotes the dispersion of hydrotalcites particles. After modification, the shape of peak did not changed, which indicated NTP treatment process is physical effect did not changed the structure of NiAl-LDHs. The structure data determined from XRD measurements are reported in Table 1. The value of the unit cell parameter $\mathrm{a}_{0}$ is equivalent to the mean distance between adjacent cation center in the close-packed cationic brucite-type sheets, thus its value can be correlated with the average value of radii of the metal cations in those layers [24]. The position of the (110) reflection allows the value of the lattice parameter $\mathrm{a}_{0}$ to be determined, since $\mathrm{a}_{0}=2 \mathrm{~d}(110)$. The basal spacing $\mathrm{c}_{0}$ of LDHs equals the thickness of one brucite-type layer plus one interlayer. The observed reflections in Figure 1 can be indexed in a three-layer 3R polytype; in this case the basal repeat distance $c_{0}$ is $c / 3$. The lowest reflection (003) was used to calculate $c_{0}(003)$ and c (003), respectively, as reported in Table 1 . The Scherrer equation was used to estimate the crystallite size, from the width of the (110) and (003), results shown in Table 1. Crystallite size valued calculated from the (003) line show a decrease when modified by NTP in sample NiAl-LDHs (P) compared with the NiAl-LDHs. It was indicated that the NTP treatment induced the production of high crystalline LDHs with relatively small particle size; these were benefit for adsorption process. After adsorption of fluoride the basal spacing $\mathrm{c}_{0}$ and crystallite size of NiAl-LDHs and NiAl-LDHs (P) became smaller than before. This indicated that $\mathrm{F}^{-}$has been adsorbed in the gallery of NiAl-LDHs.

The FTIR spectra of the NiAl-LDHs and NiAl-LDHs (P) are given in Figure 2. The strong peak at $3440 \mathrm{~cm}^{-1}$ was attributed to the stretching vibrations of $-\mathrm{OH}$ groups associated with the interlayer water molecules and hydrogen bonding. The H-O-H bending vibration of the interlayer molecule water was located at $1624 \mathrm{~cm}^{-1}$ [27] [28].

In addition, two intense peaks around 705 and $1387 \mathrm{~cm}^{-1}$ due to the $\bar{v}_{2}$ (out-of-plane deformation) and $\bar{v}_{3}$ (symmetric stretching) vibrations of the interlayer carbonate anions. The bands in the range of $500-800 \mathrm{~cm}^{-1}$ are attributed to O-M-O, and M-O-M lattice vibrations ( $\mathrm{M}=\mathrm{Ni}$ and $\mathrm{Al})$ [16] [29].

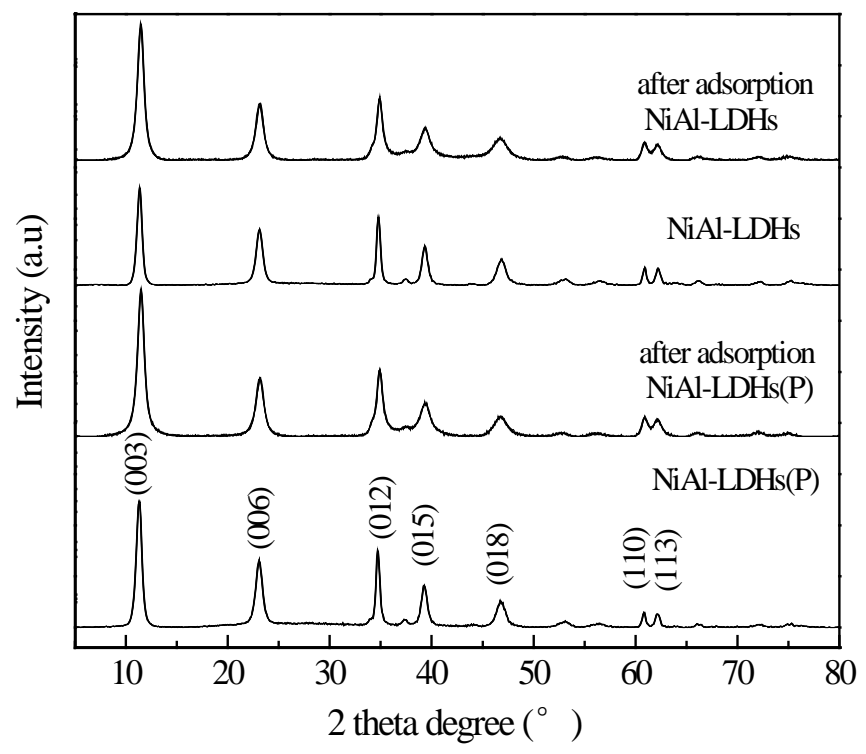

Figure 1. XRD patterns of NiAl-LDHs and NiAl-LDHs (P). 
Table 1. Structure parameters of the NiAl-LDHs samples.

\begin{tabular}{cccccccc}
\hline Sample & $\mathrm{d}(003) \AA$ & \multicolumn{2}{c}{ Crystallite size $(\mathrm{nm})$} & \multicolumn{4}{c}{ Lattice parameters $(\AA)$} \\
\hline NiAl-LDHs (P) & & $\mathrm{D}(003)$ & $\mathrm{D}(110)$ & $\mathrm{a}_{0}(110)$ & $\mathrm{c}(003)$ & $\mathrm{c}_{0}(003)$ \\
NiAl-LDHs & 7.769 & 21.23 & 41.52 & 3.041 & 23.307 & 7.769 \\
After adsorption NiAl-LDHs (P) & 7.783 & 24.00 & 44.19 & 3.037 & 23.349 & 7.783 \\
After adsorption NiAl-LDHs & 7.688 & 15.79 & 33.41 & 3.053 & 23.06 & 7.688 \\
\hline
\end{tabular}

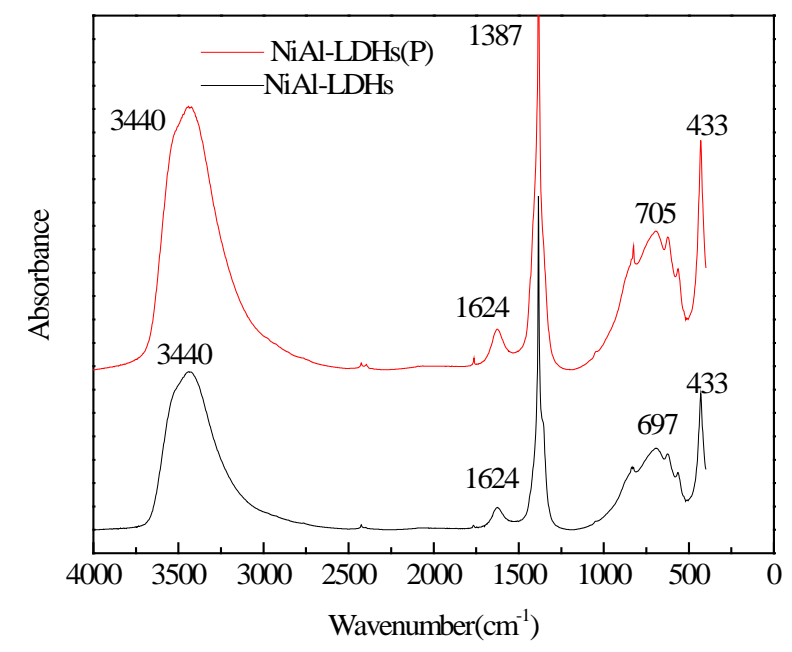

Figure 2. FT-IR spectra of two prepared samples.

The TG-DTA curves of the synthesized samples were presented in Figure 3. The weight loss occurs essentially in two steps: the first one at a low temperature $\left(30^{\circ} \mathrm{C}-150^{\circ} \mathrm{C}\right)$ corresponds to the removal of weakly adsorbed water on the external surface of the crystallites as well as water intercalated in the interlayer galleries; the second one in a wide temperature range of $\left(\mathrm{ca} .150^{\circ} \mathrm{C}-600^{\circ} \mathrm{C}\right)$ involves dehydroxylation of the layers as well as removal of volatile species $\left(\mathrm{CO}_{2}\right)$ arising from the interlayer carbonate anion [16]. Furthermore, the similar TGA curve was observed of NiAl-LDHs(P), suggesting that NTP treatment is physical modification, the characters of the materials are not changed. According to the TG analysis, the total weight loss was $56.03 \%, 41.40 \%$ for NiAl-LDHs and NiAl-LDHs (P) during the thermal decomposition process, respectively.

Figure 4 shows the $\mathrm{N}_{2}$ adsorption-desorption isotherms of NiAl-LDHs and NiAl-LDHs (P) (Figure 4(a)) and their corresponding pore size distribution (Figure 4(b)). The materials exhibited type IV isotherms according to the classification of Sing et al. [30], which are typical for mesoporous materials. Isotherms also exhibit an H3 type hysteresis at high relative pressure, which is typical for aggregates of plate-like particles giving rise to slit-shape pores [19]. This kind of hysteresis is typical for the presence of open large pores, which allow easy diffusion of the reactants through the materials. As seen from Figure 4(b), the curves are quite broad with small mesopores at $4 \mathrm{~nm}$.

The smaller mesopores reflect the presence of pores within nanosheets, while larger mesopores can be associated to the pores formed between stacked nanosheets [19]. The specific surface area of the NiAl-LDHs increased from 37.091 to $39.878 \mathrm{~m}^{2} / \mathrm{g}$ and the pore volume from 0.160 to $0.178 \mathrm{~cm}^{3} / \mathrm{g}$ by treating with NTP. It was indicated that the NTP treatment induced the production of large specific surface area.

\subsection{Batch Adsorption Studies}

\subsubsection{Effect of Initial $\mathrm{pH}$}

Adsorption of $\mathrm{F}^{-}$by NiAl-LDHs was investigated at initial $\mathrm{pH}$ value ranging from 2.0 to 12.0. The experiment results were presented in Figure 5. As shown in Figure 5, no significant change was observed for $\mathrm{F}^{-}$adsorption 


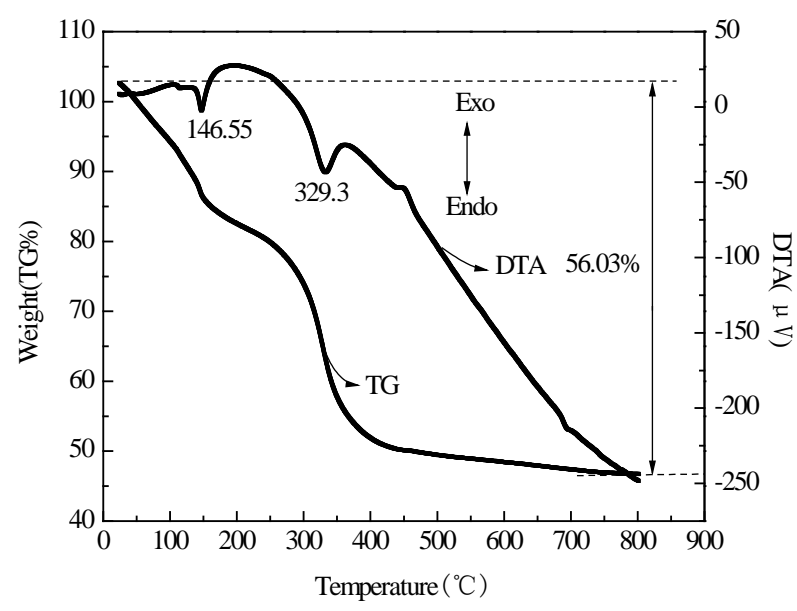

(a)

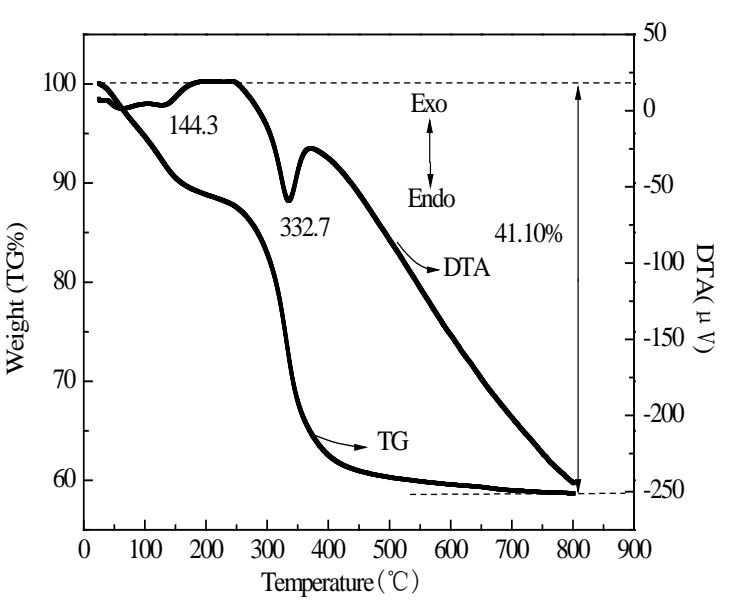

(b)

Figure 3. TG-DTA curves of the two samples: (a) NiAl-LDHs; (b) NiAl-LDHs (P).

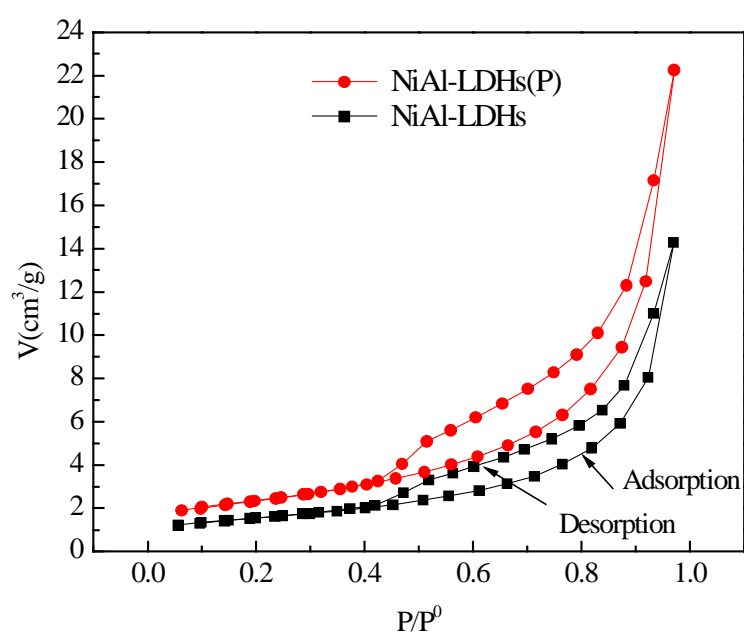

(a)

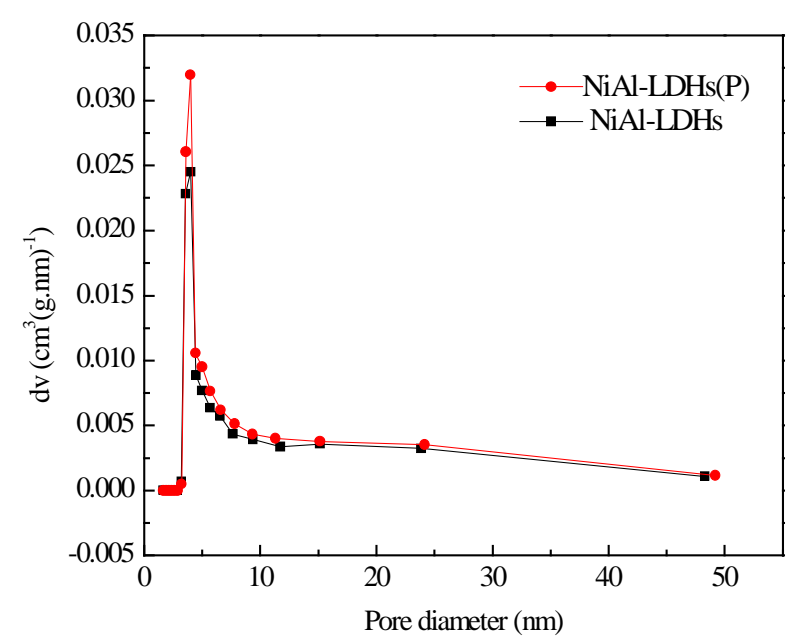

(b)

Figure 4. Nitrogen adsorption-desorption isotherms (a) and pore size distribution curves; (b) of two prepared samples.

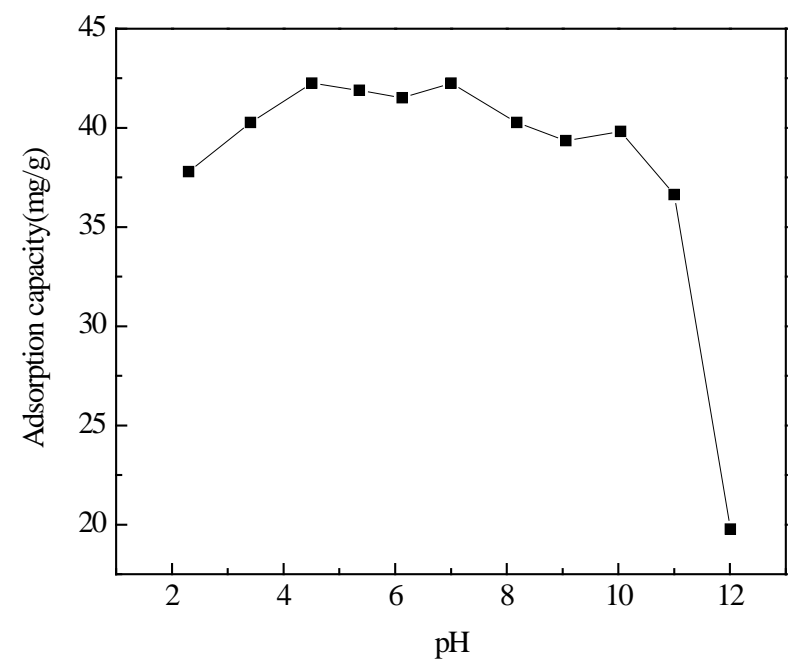

Figure 5. Effect of solution $\mathrm{pH}$ on the removal of fluoride. 
under the initial $\mathrm{pH}$ ranging from 4.5 - 10.0. While, at the initial $\mathrm{pH}<3$, the quite low adsorption capacity for $\mathrm{F}^{-}$ ions can be attributed to a partial dissolution of NiAl-LDHs by acidic hydrolysis;

$$
\begin{gathered}
\mathrm{NiAlF}+\mathrm{H}^{+} \rightleftharpoons \mathrm{NiAl}^{+}+\mathrm{HF} \\
\mathrm{H}^{+}+\mathrm{F}^{-} \rightleftharpoons \mathrm{HF}
\end{gathered}
$$

In additional, under acid condition the $\mathrm{CO}_{3}^{2-}$ ion which presence in NiAl-LDHs interlayer could combine with $\mathrm{H}^{+}$:

$$
\begin{gathered}
\mathrm{CO}_{3}^{2-}+\mathrm{H}^{+} \rightleftharpoons \mathrm{HCO}_{3}^{-} \\
\mathrm{HCO}_{3}^{-}+\mathrm{H}^{+} \rightleftharpoons \mathrm{H}_{2} \mathrm{CO}_{3}
\end{gathered}
$$

The $\mathrm{HCO}_{3}^{-}$anions was introduced on the surface of NiAl-LDHs, which could provide less adsorption sites for fluoride and reduce the adsorption capacity.

At $\mathrm{pH}$ ranging from 3.0 to 7.0 , the removal efficiency of $\mathrm{F}^{-}$increased from $80.54 \%$ to $84.49 \%$, showing a mild plateau between $\mathrm{pH} 4.5$ and 7.0 with the removal percentage above $83.0 \%$.

But at much higher $\mathrm{pH}$ (pH 11.0) condition, adsorption amount of $\mathrm{F}^{-}$decreased to a large extent. The removal efficiency of $\mathrm{F}^{-}$reached about $39.52 \%$ at initial $\mathrm{pH}$ 12.0. It could be due to the competition between $\mathrm{OH}^{-}$and $\mathrm{F}^{-}$.

$$
\mathrm{NiAlF}+\mathrm{OH}^{-} \rightleftharpoons \mathrm{NiAl}(\mathrm{OH})+\mathrm{F}^{-}
$$

Both of hydrolysis and competition of $\mathrm{OH}^{-}$ion will directly reduce the absorption capacity of NiAl-LDHs. The NiAl-LDHs could work well at the $\mathrm{pH}$ range from 4.5 - 10.0. All the results above indicated that the synthesized NiAl-LDHs samples have high $\mathrm{pH}$ buffering ability.

\subsubsection{Effect of Co-Anions}

Since other anions can compete with fluoride ion in the adsorption process, the selectivity of NiAl-LDHs for the $\mathrm{F}^{-}$was investigated in the co-anions systems of some anionic species such as $\mathrm{NO}_{2}^{-}, \mathrm{MnO}_{4}^{-}, \mathrm{HPO}_{4}^{2-}, \mathrm{CO}_{3}^{2-}$, $\mathrm{SO}_{4}^{2-}, \mathrm{C}_{2} \mathrm{O}_{4}^{2-}$ and $\mathrm{PO}_{4}^{3-}$, all species typically found in fluoride containing waste water. The percent of adsorption by the NiAl-LDHs from the solution contains $100 \mathrm{mg} / \mathrm{L}$ of each anion as shown in Figure 6.

It can be seen that in the presence of co-anions the order of fluoride adsorption capacity is: $\mathrm{PO}_{4}^{3-}<\mathrm{HPO}_{4}^{2-}$ $<\mathrm{CO}_{3}^{2-}<\mathrm{SO}_{4}^{2-}<\mathrm{C}_{2} \mathrm{O}_{4}^{2-}<\mathrm{MnO}_{4}^{-}<\mathrm{NO}_{2}^{-}$. The divalent and trivalent anions have more effect than monovalent anions on adsorption capacity, similar results were observed in the literature for fluoride adsorption by Li/Al-LDHs [31]. This may be due to a high negative charge density of ions which were easily absorbed by the

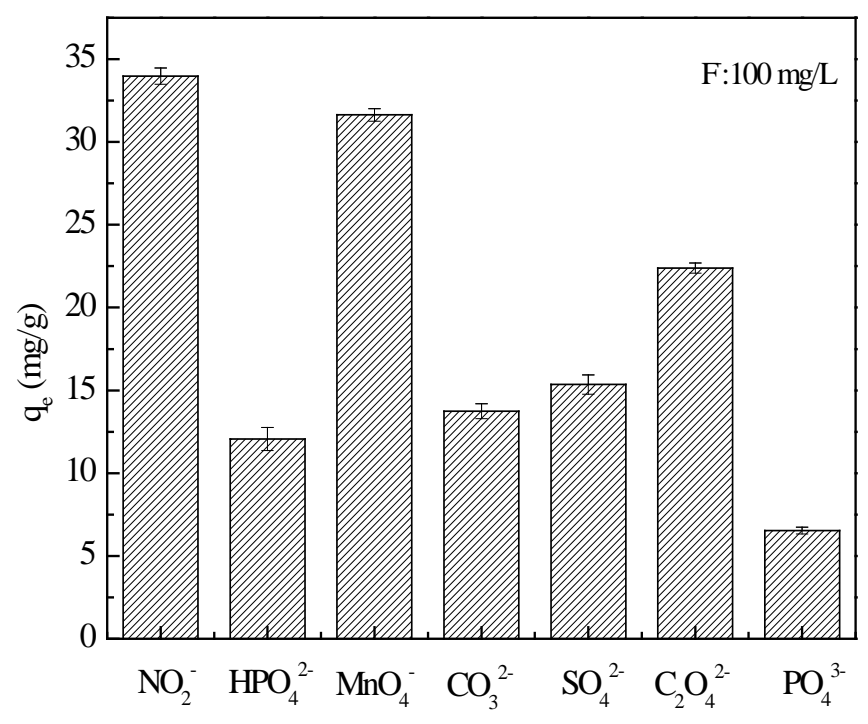

Figure 6. Effect of solution co-anions on the removal of fluoride. 
layer positive charge. The competitive anions were introduced on the surface of NiAl-LDHs, which can provide less adsorption sites for fluoride and reduced the adsorption capacity.

The presence of $\mathrm{NO}_{2}^{-}$ion in solution, the adsorption amount reached $33.98 \mathrm{mg} / \mathrm{g}$, while the presence of $\mathrm{PO}_{4}^{3-}$ ion only had $6.534 \mathrm{mg} / \mathrm{g}$. The $\mathrm{PO}_{4}^{3-}$ ion appears to display a maximum interference for $\mathrm{F}^{-}$ion. Halajnia et al. [32] showed that some physical properties of LDHs such as crystallinity, porosity, particle size, surface area and interlayer space characteristics can have great effects in adsorption.

\subsection{Fluoride Adsorption Kinetic Studies}

The adsorption kinetics is important for adsorption studies because it can predict the rate which fluoride is removed from aqueous solutions and provide valuable data for understanding the mechanism of sorption reactions [19]. Kinetics adsorption of $\mathrm{F}^{-}$on NiAl-LDHs was investigated in the presence of $2.0 \mathrm{~g} / \mathrm{L}$ of adsorbent at $25^{\circ} \mathrm{C}$. Figure 7 shows that the adsorption rates were considerably fast under all the concentrations. The adsorption process almost finished within $30 \mathrm{~min}$, and no significant change was observed from 30 to $90 \mathrm{~min}$. This observation may be associated with the existence of a large number of vacant sites on the surface that are available for adsorption during the initial stage. However, the remaining vacant surface sites are less available for adsorption with time due to the repulsive forces that occur between the adsorbed and free molecules [28]. The phenomenon that the adsorption reached equilibrium quickly indicated that the adsorption of $\mathrm{F}^{-}$on NiAl-LDHs was mainly attributed to chemical sorption or surface reaction. The binding of $\mathrm{F}^{-}$anions on the surface of NiAl-LDHs may be ascribed to the strong electrostatic interaction between $\mathrm{F}^{-}$and NiAl-LDHs layered structures. The other mechanism for $\mathrm{F}^{-}$adsorption is due to ion exchange between the intercalated anions of NiAl-LDHs with $\mathrm{F}^{-}$ion. The removal efficiencies were found to be $93.4 \%, 85.7 \%, 74.2 \%$ at the initial $\mathrm{F}^{-}$concentrations of $60.0,80.0$ and $100.0 \mathrm{mg} / \mathrm{L}$, respectively. According to Halajnia and Oustan [32] the percentage removal at equilibrium depends on the type of LDHs as well as the initial concentration. On the other hand, seen from the removal time figure, with the increase of the initial $\mathrm{F}^{-}$concentrations from 60 to $100 \mathrm{mg} / \mathrm{L}$, the total amount of $\mathrm{F}^{-}$adsorbed increased from 28.02 to $37.12 \mathrm{mg} / \mathrm{g}$. It could be attributed that more targets of $\mathrm{F}^{-}$could provide higher driving force to facilitate the ions diffusion from the solution to NiAl-LDHs, and more collisions between $\mathrm{F}^{-}$ions and active sites of the samples. Similar phenomena have also been observed in the literature [33].

The experimental data were modeled by three adsorption kinetic models, pseudo-first-order model (Equation (8)), pseudo-second-order model (Equation (9)), and intra-particle diffusion model (Equation (10)) [31] [32] [34].

Pseudo-first-order model: $\ln \left(q_{e}-q_{t}\right)=\ln q_{e}-k_{1} t$

Pseudo-second-order model: $\frac{t}{q_{t}}=\frac{1}{k_{2} q_{e}{ }^{2}}+\frac{t}{q_{e}}$

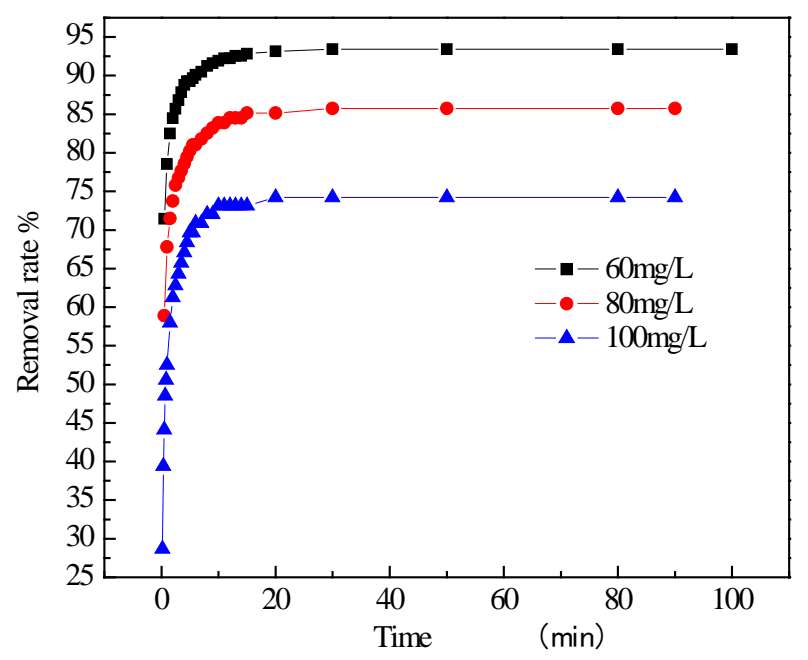

Figure 7. Effect of time on the adsorption of $\mathrm{F}^{-}$. 


$$
\text { Intra-particle diffusion model: } q_{t}=k_{p} t^{1 / 2}+C
$$

where $q_{e}$ and $q_{t}$ are the amount of $\mathrm{F}^{-}$adsorbed $(\mathrm{mg} / \mathrm{g})$ at equilibrium and at time $t$ (min), respectively and $k_{1}$ is the pseudo-first-order rate constant $\left(\mathrm{min}^{-1}\right)$. Values of $k_{1}$ are calculated from the plots of $\ln \left(q_{e}-q_{t}\right)$ versus $t$ for the adsorbent samples; $k_{2}$ is the pseudo-second-order rate constant $\left(\mathrm{g} \cdot \mathrm{mg}^{-1} \cdot \mathrm{min}^{-1}\right)$. Based on the experimental data of $q_{t}$ and $t$, the equilibrium adsorption capacity $q_{e}$ and $k_{2}$ can be determined from the slope and intercept of a plot of $t / q_{t}$ versus $t$; $k_{p}$ is intra-particular diffusion rate constant $\left(\mathrm{mg} \cdot \mathrm{g}^{-1} \cdot \mathrm{min}^{-0.5}\right)$. If intra-particular diffusion is rate-limited, then plots of adsorbate uptake $q_{t}$ versus the square root of time $\left(t^{0.5}\right)$ would result in a linear relationship.

From the slope and intercept of the straight line obtained, the kinetic parameters for the removal of fluoride were determined, as compiled in Table 2 and the plots of the linearized from the pseudo-second-order model are shown in Figure 8. The goodness-of-fit for the models were assessed by calculating the coefficient of determination $\left(\mathrm{R}^{2}\right)$. It can be seen from Table 2, the $\mathrm{R}^{2}$ values obtained from pseudo-first-order model are relatively small and the experimental $q_{e}$ values do not agree with the values calculated from the linear plots, while the experimental $q_{e}$ values were more close to the calculated $q_{e}$ values from the pseudo-second-order model $\left(\mathrm{R}^{2} \approx 1\right)$. This indicated the better performance of the pseudo-second-order model to describe fluoride adsorption on the NiAl-LDHs. This results similar to as found in most studies [20] [35] [36].

Table 2. Kinetic model parameters for adsorption of fluoride.

\begin{tabular}{|c|c|c|c|c|c|c|c|}
\hline \multirow[b]{2}{*}{$\begin{array}{c}C_{o} \\
\left(\mathrm{mg} \cdot \mathrm{L}^{-1}\right)\end{array}$} & \multirow[b]{2}{*}{$\begin{array}{c}q_{e, \exp } \\
\left(\mathrm{mg} \cdot \mathrm{g}^{-1}\right)\end{array}$} & \multicolumn{3}{|c|}{ Pseudo-first-order } & \multicolumn{3}{|c|}{ Pseudo-second-order } \\
\hline & & $\begin{array}{c}q_{e 1, \text { cal }} \\
\left(\mathrm{mg} \cdot \mathrm{g}^{-1}\right)\end{array}$ & $\begin{array}{c}k_{1} \\
\left(\min ^{-1}\right)\end{array}$ & $\mathrm{R}^{2}$ & $\begin{array}{c}q_{e 2, \mathrm{cal}} \\
\left(\mathrm{mg} \cdot \mathrm{g}^{-1}\right)\end{array}$ & $\begin{array}{c}k_{2} \\
\left(\mathrm{~g} \cdot \mathrm{mg}^{-1} \cdot \mathrm{min}^{-1}\right)\end{array}$ & $\mathrm{R}^{2}$ \\
\hline 60 & 28.02 & 2.363 & 0.01385 & 0.3565 & 28.10 & 0.1810 & 1.000 \\
\hline 80 & 34.30 & 3.105 & 0.02409 & 0.4681 & 34.45 & 0.09533 & 1.000 \\
\hline 100 & 37.12 & 5.312 & 0.03916 & 0.4167 & 37.36 & 0.07656 & 0.9999 \\
\hline \multicolumn{8}{|c|}{ Intraparticle diffusion } \\
\hline $\begin{array}{c}C_{o} \\
\left(\mathrm{mg} \cdot \mathrm{L}^{-1}\right)\end{array}$ & $\begin{array}{c}q_{e, \exp } \\
\left(\mathrm{mg} \cdot \mathrm{g}^{-1}\right)\end{array}$ & $\begin{array}{c}K_{p 1} \\
\left(\mathrm{mg} \cdot \mathrm{g}^{-1} \cdot \mathrm{min}^{-0.5}\right)\end{array}$ & $\mathrm{R}_{1}^{2}$ & $\begin{array}{c}K_{p 2} \\
\left(\mathrm{mg} \cdot \mathrm{g}^{-1} \cdot \mathrm{min}^{-0.5}\right)\end{array}$ & $\mathrm{R}_{2}^{2}$ & $\begin{array}{c}K_{p 3} \\
\left(\mathrm{mg} \cdot \mathrm{g}^{-1} \cdot \min ^{-0.5}\right)\end{array}$ & $\mathrm{R}_{3}^{2}$ \\
\hline 60 & 28.02 & 3.769 & 0.9279 & 0.7200 & 0.9753 & 0.03125 & 0.5724 \\
\hline 80 & 34.30 & 5.664 & 0.9157 & 1.365 & 0.9720 & 0.06186 & 0.6042 \\
\hline 100 & 37.12 & 15.32 & 0.9413 & 3.333 & 0.9187 & 0.1158 & 0.6409 \\
\hline
\end{tabular}

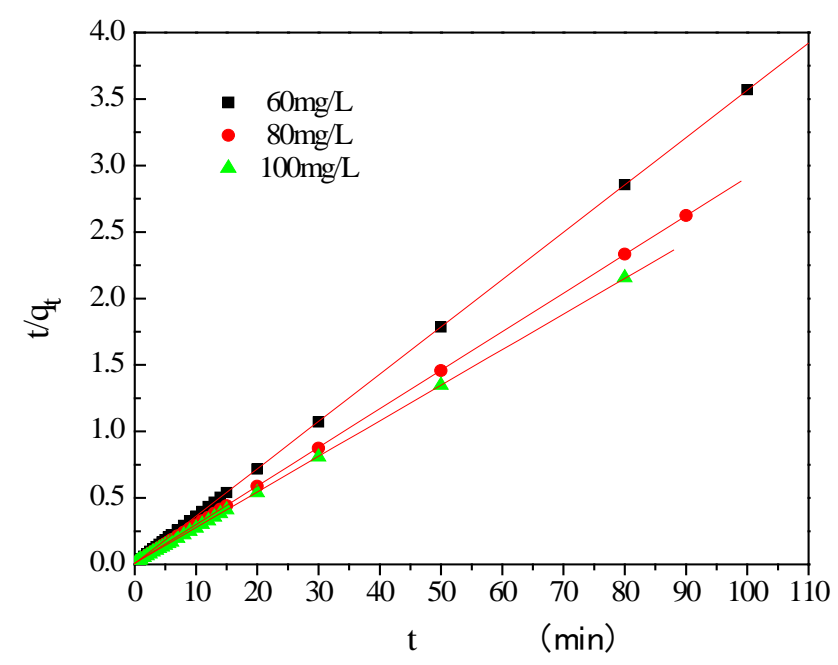

Figure 8. Pseudo-second-order kinetic for adsorption of fluoride. 
The rate-limiting step in the adsorption process is the "surface reaction". The maximum percent removal could reach $93.41 \%$, and the equilibrium concentration was $3.956 \mathrm{mg} / \mathrm{L}$ for the initial fluoride concentration of $60 \mathrm{mg} / \mathrm{L}$. With increasing concentration from 60 to $100 \mathrm{mg} / \mathrm{L}$, the rate constant of pseudo-second-order, $k_{2}$ decreases from $18.10 \times 10^{-2}$ to $7.656 \times 10^{-2} \mathrm{~g} \cdot \mathrm{mg}^{-1} \cdot \mathrm{min}^{-1}$, this fact was supported by Figure 7 . A similar phenomenon is observed in adsorption of methyl orange onto LDHs [30]. The adsorption kinetics of fluoride in NiAl-LDHs can be divided into two stages: a fast adsorption step and a slow adsorption step. In order to determine the rate-limiting the diffusion mechanism in the adsorption of fluoride on NiAl-LDHs can describe by the intra-particle diffusion model. It can be seen from Table 2 that the adsorption conducted in multiple steps. At first, is the external surface adsorption stage, which was driven by initial fluoride concentration different. The second is the gradual adsorption stage, where intra-particle diffusion is the rate limiting step. The third is the final equilibrium stage where intra-particle diffusion further slows down due to the fluoride concentration decreased in the solutions. These results are consistent with literature [30] [33]. It is clear from the values of $\mathrm{R}^{2}$ in Table 2 that $\mathrm{F}^{-}$ion adsorption kinetics on NiAl-LDHs sample was better described by pseudo-second-order model and intra-particle diffusion model.

\section{Conclusion}

The NiAl-LDHs with high sorption capacity for fluoride have been successfully modified by a remarkably simple and efficient NTP treatment process. The surfaces area of the modified samples by NTP has changed from 37.091 to $39.878 \mathrm{~m}^{2} / \mathrm{g}$. The NTP treatment is physical modification, which does not destroy the structure of materials as well as reduce the pollution of the environment and increases the active adsorption sites, resulting in adsorption capacity enhanced. It was found that the coexisting anions have little effect on the removal of fluoride, except for $\mathrm{PO}_{4}^{3-}$. The underlying adsorption kinetics follows the pseudo-second-order model and intraparticle diffusion model. The adsorption equilibrium concentration of fluoride in solution was $0.2388 \mathrm{mg} / \mathrm{L}$, reached the standard of the fluoride limit in drinking water. The results presented here will make notable contributions to the development of modified LDHs for water purification.

\section{Acknowledgments}

We express our sincere appreciation and deepest gratitude to key laboratory of applied chemistry in Hebei province for support during this study.

\section{References}

[1] Deng, H. and Yu, X. (2012) Fluoride Sorption by Metal Ion-Loaded Fibrous Protein. Industrial \& Engineering Chemistry Research, 51, 2419-2427. http://dx.doi.org/10.1021/ie201873z

[2] Jagtap, S., Yenkie, M.K., Labhsetwar, N., et al. (2012) Fluoride in Drinking Water and Defluoridation of Water. Chemical Reviews, 112, 2454-2466. http://dx.doi.org/10.1021/cr2002855

[3] Behbahani, M., Moghaddam, M.R.A. and Arami, M. (2011) Techno-Economical Evaluation of Fluoride Removal by Electrocoagulation Process: Optimization through Response Surface Methodology. Desalination, 271, 209-218. http://dx.doi.org/10.1016/j.desal.2010.12.033

[4] Emamjomeh, M.M. and Sivakumar, M. (2009) Fluoride Removal by a Continuous Flow Electrocoagulation Reactor. Journal of Environmental Management, 90, 1204-1212. http://dx.doi.org/10.1016/j.jenvman.2008.06.001

[5] Sehn, P. (2008) Fluoride Removal with Extra Low Energy Reverse Osmosis Membranes: Three Years of Large Scale Field Experience in Finland. Desalination, 223, 73-84. http://dx.doi.org/10.1016/j.desal.2007.02.077

[6] Ho, L.N., Ishihara, T., Ueshima, S., et al. (2004) Removal of Fluoride from Water through Ion Exchange by Mesoporous Ti Oxohydroxide. Journal of Colloid and Interface Science, 272, 399-403. http://dx.doi.org/10.1016/j.jcis.2003.08.051

[7] Alkan, E., Kır, E. and Oksuz, L. (2008) Plasma Modification of the Anion-Exchange Membrane and Its Influence on Fluoride Removal from Water. Separation and Purification Technology, 61, 455-460. http://dx.doi.org/10.1016/j.seppur.2007.12.012

[8] Kemer, B., Ozdes, D., Gundogdu, A., et al. (2009) Removal of Fluoride Ions from Aqueous Solution by Waste Mud. Journal of Hazardous Materials, 168, 888-894. http://dx.doi.org/10.1016/j.jhazmat.2009.02.109

[9] Lai, Y.-L., Thirumavalavan, M. and Lee, J.-F. (2010) Effective Adsorption of Heavy Metal Ions $\left(\mathrm{Cu}^{2+}, \mathrm{Pb}^{2+}, \mathrm{Zn}^{2+}\right)$ from Aqueous Solution by Immobilization of Adsorbents on Ca-Alginate Beads. Toxicological \& Environmental Che- 
mistry, 92, 697-705. http://dx.doi.org/10.1080/02772240903057382

[10] Zhong, Y., Yang, Q., Luo, K., et al. (2013) Fe(II)-Al(III) Layered Double Hydroxides Prepared by Ultrasound-Assisted Co-Precipitation Method for the Reduction of Bromate. Journal of Hazardous Materials, 250-251, 345-353. http://dx.doi.org/10.1016/j.jhazmat.2013.01.081

[11] Wang, D.-Y., Costa, F.R., Vyalikh, A., et al. (2009) One-Step Synthesis of Organic LDH and Its Comparison with Regeneration and Anion Exchange Method. Chemistry of Materials, 21, 4490-4497.

http://dx.doi.org/10.1021/cm901238a

[12] Berber, M.R., Hafez, I.H., Minagawa, K., et al. (2013) Uniform Nanoparticles of Hydrotalcite-Like Materials and Their Textural Properties at Optimized Conditions of Urea Hydrothermal Treatment. Journal of Molecular Structure, 1033, 104-112. http://dx.doi.org/10.1016/j.molstruc.2012.08.028

[13] Zheng, Y.-M., Li, N. and Zhang, W.-D. (2012) Preparation of Nanostructured Microspheres of Zn-Mg-Al Layered Double Hydroxides with High Adsorption Property. Colloids and Surfaces A: Physicochemical and Engineering Aspects, 415, 195-201. http://dx.doi.org/10.1016/j.colsurfa.2012.10.014

[14] Zhao, L., Li, X., Hao, C., et al. (2012) $\mathrm{SO}_{2}$ Adsorption and Transformation on Calcined NiAl Hydrotalcite-Like Compounds Surfaces: An in Situ FTIR and DFT Study. Applied Catalysis B: Environmental, 117-118, 339-345. http://dx.doi.org/10.1016/j.apcatb.2012.01.034

[15] Wei, J., Wang, J., Song, Y., et al. (2012) Synthesis of Self-Assembled Layered Double Hydroxides/Carbon Composites by in Situ Solvothermal Method and Their Application in Capacitors. Journal of Solid State Chemistry, 196, 175181. http://dx.doi.org/10.1016/j.jssc.2012.06.009

[16] Liu, Q., Fan, G., Zhang, S., Liu, Y. and Li, F. (2012) Synthesis of Uniform Ni-Al Layered Double Hydroxide via a Novel Reduction-Oxidation Route. Materials Letters, 82, 4-6.

[17] Fang, J., Li, M., Li, Q., Zhang, W., Shou, Q., Liu, F., et al. (2012) Microwave-Assisted Synthesis of CoAl-Layered Double Hydroxide/Graphene Oxide Composite and Its Application in Supercapacitors. Electrochimica Acta, 85, 248255. http://dx.doi.org/10.1016/j.electacta.2012.08.078

[18] Garcia-Gallastegui, A., Iruretagoyena, D., Gouvea, V., Mokhtar, M., Asiri, A.M., Basahel, S.N., et al. (2012) Graphene Oxide as Support for Layered Double Hydroxides: Enhancing the $\mathrm{CO}_{2}$ Adsorption Capacity. Chemistry of Materials, 24, 4531-4539. http://dx.doi.org/10.1021/cm3018264

[19] Zhou, J., Yang, S., Yu, J. and Shu, Z. (2011) Novel Hollow Microspheres of Hierarchical Zinc-Aluminum Layered Double Hydroxides and Their Enhanced Adsorption Capacity for Phosphate in Water. Journal of Hazardous Materials, 192, 1114-1121. http://dx.doi.org/10.1016/j.jhazmat.2011.06.013

[20] Zhang, T., Li, Q., Liu, Y., Duan, Y. and Zhang, W. (2011) Equilibrium and Kinetics Studies of Fluoride Ions Adsorption on $\mathrm{CeO}_{2} / \mathrm{Al}_{2} \mathrm{O}_{3}$ Composites Pretreated with Non-Thermal Plasma. Chemical Engineering Journal, 168, 665-671. http://dx.doi.org/10.1016/j.cej.2011.01.054

[21] Bromberg, L., Cohn, D.R. and Rabinovich, A. (1998) Plasma Reforming of Methane. Energy \& Fuels, 12, 11-18. http://dx.doi.org/10.1021/ef9701091

[22] Li, Q., Wu, J. and Hao, J. (2011) $\mathrm{NO}_{\mathrm{x}}$ Storage Capacity Enhancement on $\mathrm{NiO} / \mathrm{Al}_{2} \mathrm{O}_{3}$ Pretreated with a Non-Thermal Plasma. Chinese Journal of Catalysis, 32, 572-581. http://dx.doi.org/10.1016/S1872-2067(10)60191-X

[23] Li, Q., Lu, H., Xiao, H., Gaoa, K. and Diao, M. (2013) Adsorption Capacity of Superabsorbent Resin Composite Enhanced by Non-Thermal Plasma and Its Adsorption Kinetics and Isotherms to Lead Ion in Water. Journal of Environmental Chemical Engineering, 1, 996-1003. http://dx.doi.org/10.1016/j.jece.2013.08.010

[24] Jitianu, M., Gunness, D.C., Aboagye, D.E., Zaharescuc, M. and Jitianu, A. (2013) Nanosized Ni-Al Layered Double Hydroxides-Structural Characterization. Materials Research Bulletin, 48, 1864-1873. http://dx.doi.org/10.1016/j.materresbull.2013.01.030

[25] Shao, M., Ning, F., Zhao, Y., Zhao, J., Wei, M., Evans, D.G., et al. (2012) Core-Shell Layered Double Hydroxide Microspheres with Tunable Interior Architecture for Supercapacitors. Chemistry of Materials, 24, 1192-1197. http://dx.doi.org/10.1021/cm203831p

[26] Keleşoğlu, S., Kes, M., Sütçü, L. and Polat, H. (2011) Adsorption of Methylene Blue from Aqueous Solution on High Lime Fly Ash: Kinetic, Equilibrium, and Thermodynamic Studies. Journal of Dispersion Science and Technology, 33, 15-23. http://dx.doi.org/10.1080/01932691.2010.528677

[27] Wu, Y., Yu, Y., Zhou, J.Z., Liu, J., Chi, Y., Xu, Z.P., et al. (2012) Effective Removal of Pyrophosphate by Ca-Fe-LDH and Its Mechanism. Chemical Engineering Journal, 179, 72-79. http://dx.doi.org/10.1016/j.cej.2011.10.053

[28] de Sá, F.P., Cunha, B.N. and Nunes, L.M. (2013) Effect of pH on the Adsorption of Sunset Yellow FCF Food Dye into a Layered Double Hydroxide (CaAl-LDH-NO $\mathrm{N}_{3}$ ). Chemical Engineering Journal, 215-216, 122-127. http://dx.doi.org/10.1016/j.cej.2012.11.024 
[29] Wen, T., Wu, X., Tan, X., Wang, X. and Xu, A. (2013) One-Pot Synthesis of Water-Swellable Mg-Al Layered Double Hydroxides and Graphene Oxide Nanocomposites for Efficient Removal of As(V) from Aqueous Solutions. ACS Applied Materials \& Interfaces, 5, 3304-3311. http://dx.doi.org/10.1021/am4003556

[30] Zaghouane-Boudiaf, H., Boutahala, M. and Arab, L. (2012) Removal of Methyl Orange from Aqueous Solution by Uncalcined and Calcined MgNiAl Layered Double Hydroxides (LDHs). Chemical Engineering Journal, 187, $142-149$. http://dx.doi.org/10.1016/j.cej.2012.01.112

[31] Zhang, T., Li, Q., Xiao, H., Lu, H. and Zhou, Y. (2012) Synthesis of Li-Al Layered Double Hydroxides (LDHs) for Efficient Fluoride Removal. Industrial \& Engineering Chemistry Research, 51, 11490-11498. http://dx.doi.org/10.1021/ie300863x

[32] Halajnia, A., Oustan, S., Najafi, N., Khataee, A.R. and Lakzian, A. (2012) The Adsorption Characteristics of Nitrate on Mg-Fe and Mg-Al Layered Double Hydroxides in a Simulated Soil Solution. Applied Clay Science, 70, 28-36. http://dx.doi.org/10.1016/j.clay.2012.09.007

[33] Gong, J., Liu, T., Wang, X., Hu, X. and Zhang, L. (2011) Efficient Removal of Heavy Metal Ions from Aqueous Systems with the Assembly of Anisotropic Layered Double Hydroxide Nanocrystals@Carbon Nanosphere. Environmental Science \& Technology, 45, 6181-6187. http://dx.doi.org/10.1021/es200668q

[34] Sui, M., Zhou, Y., Sheng, L. and Duan, B. (2012) Adsorption of Norfloxacin in Aqueous Solution by Mg-Al Layered Double Hydroxides with Variable Metal Composition and Interlayer Anions. Chemical Engineering Journal, 210, 451460. http://dx.doi.org/10.1016/j.cej.2012.09.026

[35] Swain, S.K., Patnaik, T., Singh, V.K., Jha, U., Patel, R.K. and Dey, R.K. (2011) Kinetics, Equilibrium and Thermodynamic Aspects of Removal of Fluoride from Drinking Water Using Meso-Structured Zirconium Phosphate. Chemical Engineering Journal, 171, 1218-1226. http://dx.doi.org/10.1016/j.cej.2011.05.030

[36] Viswanathan, N. and Meenakshi, S. (2010) Selective Fluoride Adsorption by a Hydrotalcite/Chitosan Composite. Applied Clay Science, 48, 607-611. http://dx.doi.org/10.1016/j.clay.2010.03.012 
Scientific Research Publishing (SCIRP) is one of the largest Open Access journal publishers. It is currently publishing more than 200 open access, online, peer-reviewed journals covering a wide range of academic disciplines. SCIRP serves the worldwide academic communities and contributes to the progress and application of science with its publication.

Other selected journals from SCIRP are listed as below. Submit your manuscript to us via either submit@scirp.org or Online Submission Portal.
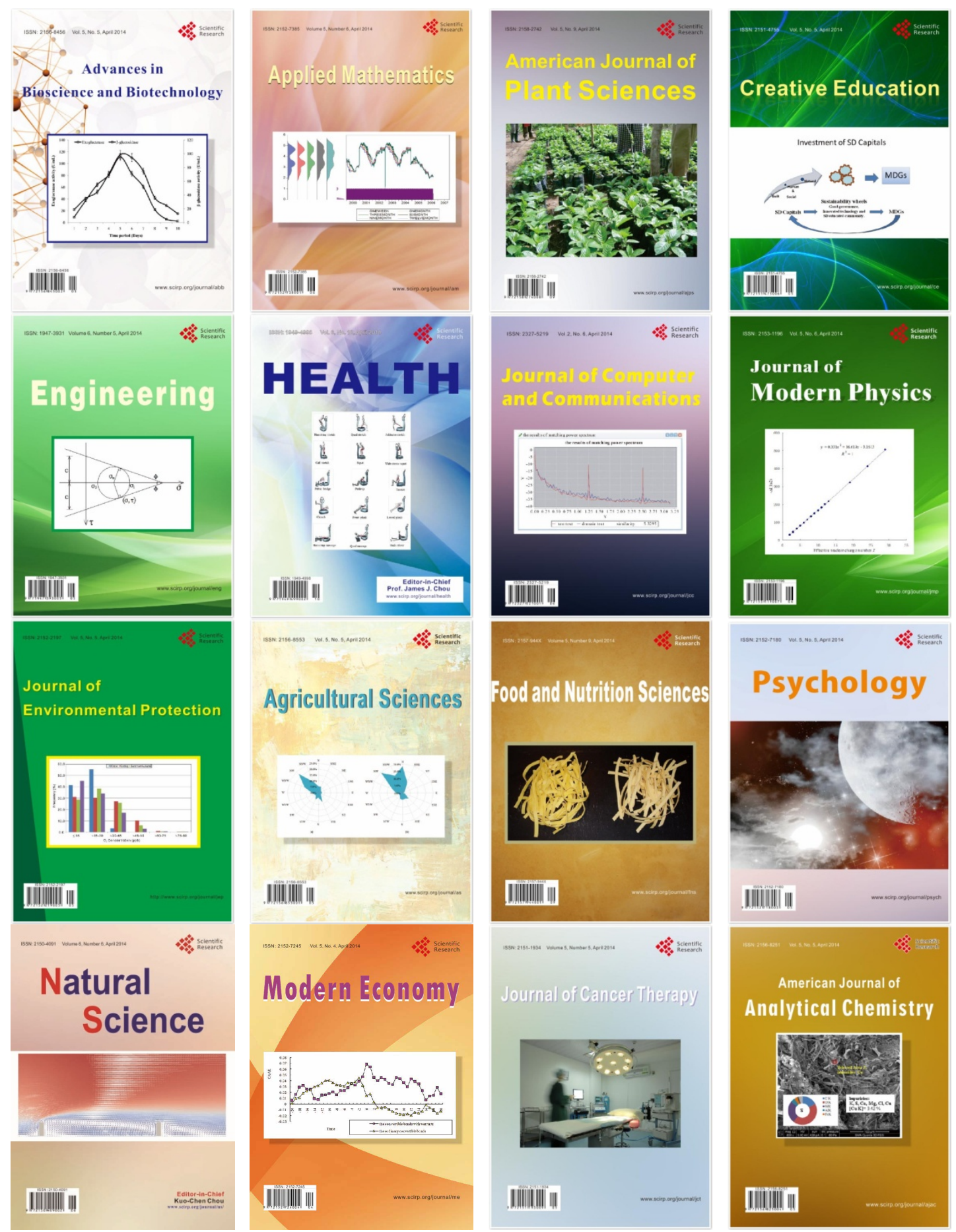